\title{
粘弾性流体の急縮小流れを対象とした数值シミュレーション
}

\section{Numerical Simulation of Flow that the Viscoelasticity Fluid by Passes the Sudden Reduction}

\author{
○学 笛吹 祐登 (福井高専) \\ 正 藤田 克志 (福井高専) \\ 正 川端 信義（金沢大学） \\ 正 大田 貴士 (福井大学)
}

Yuto USUI, Fukui National College of Technology, Geshityou, Sabae-shi, Fukui

Katsushi FUJITA, Fukui National College of Technology

Nobuyoshi KAWABATA, Kanazawa University, Kakumatyou, Kanazawa-shi, Ishikawa

Takashi OHTA, University of Fukui, 3-9-1, Bunkyo, Fukui-shi, Fukui

Key Words : Numerical Analysis, Viscoelastic Fluid, Sudden Reduction Flow, Partial Staggered Grid, Divergence Flow

\section{1 緒言}

プラスチックやゴムの原料となる各種樹脂は, 粘性と弾性 の性質を併せ持つ粘弾性流体である. 粘弾性流体は, ニュー トン流体では見られない様々な特異流れ(1)を起こすことが 知られている。例えばプラスチック・ゴム製品の射出成型・ 押出加工時においては, 流量を増加させると押し出し物表面 にしわがよる融液損傷が発生し, 製品の性質や形状などが悪 くなる. そのため, 発生を抑止するなどの目的で粘弾性流体 の特異流れの解明が求められている.

そこで本研究では，コンピュータを用いた数值シミュレー ションにより, 基本的な流れの1つである急縮小流れにおけ る粘弾性流体の流動の解析を行った. 粘弾性流体特有の流れ の一つである Divergence Flow と再循環流れの計算を行い, 実験結果との比較を行った。

以下に今回用いた主な記号を示す。

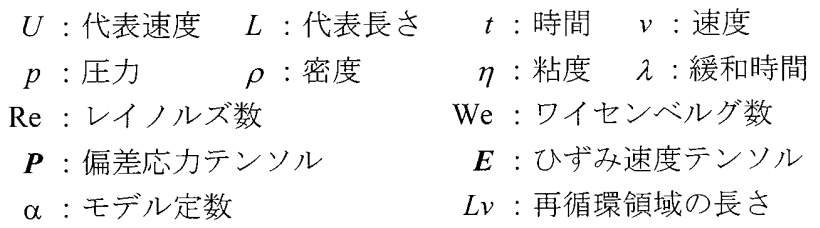

\section{2 数値計算法}

\section{1 レイノルズ数とワイセンベルグ数}

レイノルズ数 Re は慣性力と粘性力の比を, ワイセンベル グ数 We 弾性力と粘性力の比を表わすものである.

$$
\operatorname{Re}=\frac{\rho U L}{\eta}, \quad \mathrm{We}=\frac{\lambda U}{L}
$$

\section{2 基礎式}

本研究の粘弾性流体の流れの数值解析は, 粘弾性流体の等 温, 非圧縮流れと仮定したコーシーの運動方程式と連続の式, 構成方程式の三つの式を用いる.

コーシーの運動方程式は次式になる。

$$
\frac{\partial v}{\partial t}+(v \cdot \nabla) v=-\nabla p+\nabla \cdot \boldsymbol{P}
$$

連続の式は質量保存を表すもので，次式になる。

$$
\nabla \cdot v=0
$$

構成方程式は応力とひずみ速度の関係を表すものである。 モデルは多数あるが，本研究では Giesekus モデルを用いた。

$$
\boldsymbol{P}+\mathrm{We} \stackrel{\nabla}{\boldsymbol{P}}+\alpha \text { We Re } \boldsymbol{P}^{2}=-\frac{2}{\operatorname{Re}} \boldsymbol{E}
$$

$\nabla$ は upper-convected 時間微分を示し, モデル定数 $\alpha=0$ の時 に Maxwell モデルとなる.

\section{3 スタガード格子と部分スタガード格子(2)}

2 次元直交座標系のスタガード格子と部分スタガード格子 を Fig.1，Fig.2に示す．スタガード格子は，1つの格子単位 で連続の式が評価でき，圧力と速度を強くカップリングし圧 力と速度場の振動が避けられる. 部分スタガード格子は，ス タガード格子に比べて速度の境界条件を設定しやすく，境界 での圧力を決める必要がないが, 圧力と速度場の振動を避け る効果が薄いという久点がある。

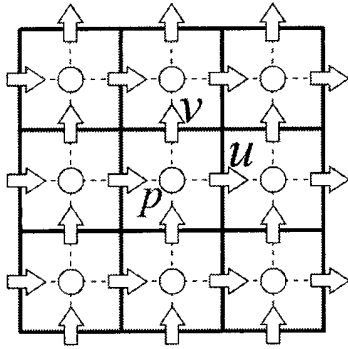

Fig.1 Staggered Grid 2.4 SMAC 法

運動方程式と連続の式から速度と圧力を求めるのに SMAC 法を使用した.SMAC 法は，速度を予測してから連続 の式を満足するように速度と圧力を修正するもので, 連続の 式を峳密に満足する特徴がある。

\section{$2.5 \quad$ Lax 法 ${ }^{(3)}$}

構成方程式から応力を求めるのに Lax 法を使用した．Lax 法は衝撃波を含むような高速気流に関する計算法で, 2 次の 拡散項省入することで安定に解こうとするものである。し かし，拡散項導入による影響が大きく，急激な変化を緩やか な変化にしてしまうので, 保存性を満足しないと考えられる. 本研究では Lax 法をクランク -ニコルソン法と組み合わせ て用いた。

\section{3 急縮小流れ}

\section{1 概要}

急縮小流れは基本的な流れの1つであり，工業的には射出 成型や押出加工に見られる. Fig.3 は高分子溶液の流れの可 視化実験の写真で, 粘弹性流体では急縮小上流側に再循環領 域と湾曲した流れである Divergence Flow が発生しているこ とが確認できる。 


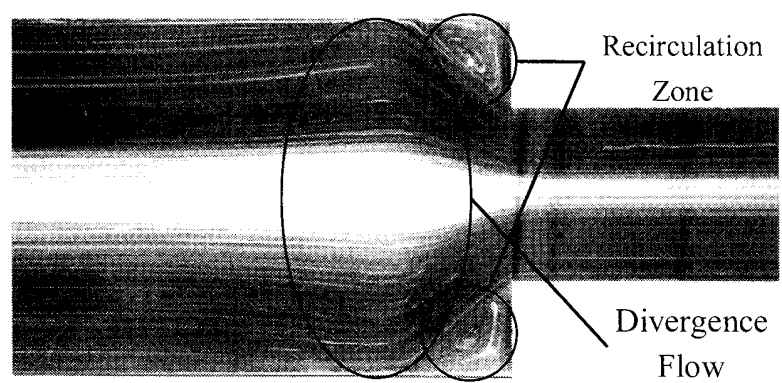

Fig.3 Result of Flow Visualization (PAA0.04\% ) ${ }^{(4)}$

\section{2 境界条件}

上下対称な流れと仮定して，中心軸を対称境界条件として 上半分だけを扱う。流入部は十分に発達した速度と忘力を用 い, 流出部に速度は対流流出条件, 応力は 1 階微分を 0 とし た.壁はノンスリップ条件とし，応力は 2 階微分を 0 とした。

\section{4 計算例}

\section{1 計算条件}

等間隔格子で流路の長さ $\mathrm{L}=10$ (急縮小部は $\mathrm{L} / 2$ の位置)， 流入側の幅 $\mathrm{D}=1$, 流出側の幅 $\mathrm{d}=\mathrm{D} / 2$, 格子数 $\mathrm{M}=400 \times 40$, 時間ステップ $\Delta \mathrm{t}$ を $10^{-3} \sim 10^{-4}$ とした以下の計算を行った.

(1) $\alpha=0$ として $\operatorname{Re}=10, \mathrm{We}=0 \sim 1$ と増加させたときのス タガード格子と部分スタガード格子の比較.

(2) $\alpha=0, \mathrm{We} / \mathrm{Re}=0.01$ として $\operatorname{Re}$ 数と We 数を増加させる.

(3) 実験で求めた $\alpha$ と $\mathrm{We} / \mathrm{Re}$ を用いた実験との比較. 今回 用いた值 ${ }^{(4)}$ を Table1 に示す。

Table1 Conditions (3)

\begin{tabular}{|c|c|c|}
\hline Experiment & PAA0.03\% & PAA0.04\% \\
\hline$\alpha$ & 0.1 & 0.03 \\
\hline $\mathrm{We} / \mathrm{Re}$ & 0.16 & 0.3 \\
\hline
\end{tabular}

\section{2 結果}

計算条件(1)の流線図の例を Fig.4，Fig.5 に示寸。部分ス夕 ガード格子では再循環領域が確認できる。しかしスタガード 格子では，流路中心に渦ができるという実際では起こりにく い流れになっている，このことから，現状ではスタガード格 子は意味のある計算結果にならないと考えられる。

計算条件(2)を部分スタガード格子で行ったときの流線図 の例を Fig.6に示す。(2)(3)の条件は流量を増加させることを 意味し, Re 数とWe 数を同時に増加させていくと徐々に流 れが湾曲していった.これが Divergence Flowだと考えられ， 再循環領域と同時に数值シミュレーションで確認できた，

計算条件(3)の比較として再循環領域の長さ $L v$ とR 数の関 係を Fig.7 に示す．全体的に計算の方が長く出て抢り，Re数 が小さい範囲では実験と近い值であるが，Re 数が大きくな ると実験との差が大きくなっている。これは，Lax 法による 数值粘性の影響と考えられる.

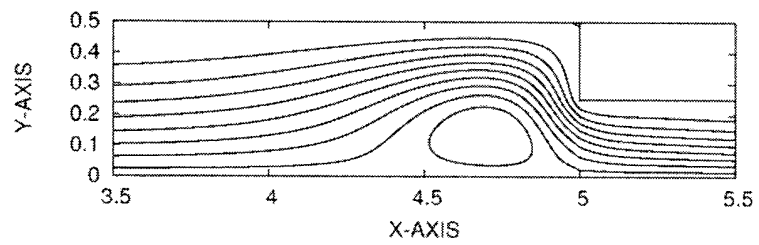

Fig.4 Streamline ( Staggered Grid, Maxwell Model, $\mathrm{Re}=10, \mathrm{We}=0.3$ )

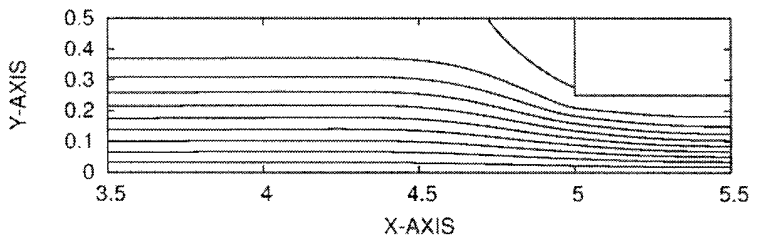

Fig.5 Streamline ( Partial Staggered Grid,

Maxwell Model $, \operatorname{Re}=10, \mathrm{We}=0.3$ )

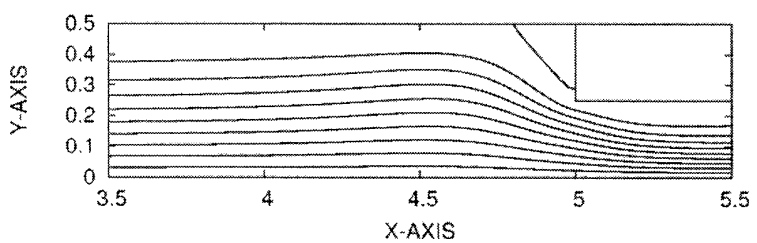

Fig.6 Streamline ( Partial Staggered Grid,

Maxwell Model, $\mathrm{We} / \mathrm{Re}=0.01, \mathrm{Re}=40, \mathrm{We}=0.4$ )

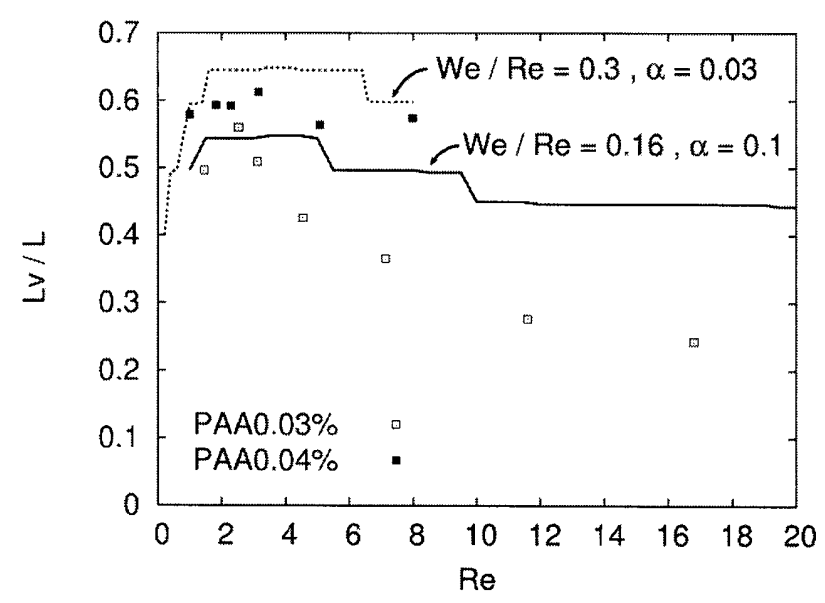

Fig.7 Length of Recirculation Zone ( Partial Staggered Grid, Giesekus Model)

\section{5 結言}

本研究では粘弾性流体の急縮小流れの数值シミュレーシ ヨンにおいて, 運動方程式に SMAC 法, 構成方程式に Lax 法を用い，スタガード格子と部分スタガード格子の比較, 流 量を増加させる計算, 可視化実験との再循環領域の長さの比 較を行ったところ，以下の結果が得られた。

・格子の違いによる比較では, スタガード格子より部分スタ ガード格子の方が自然な流れの結果になった。

・部分スタガード格子で流量を増加させる計算を行ったとこ ろ，再循環領域と Divergence Flow を同時に確認できた。

・実験との再循環領域の長さの比較では，Re 数が小さい範 囲で実験と近い結果が得られた。

\section{参考文献}

(1) Boger,D.V. and Walters FRS,K.,Rheological Phenomenaln Focas,(1993),Elsevier.

(2) J.H.ファーツィガー・M.リペッチ，「コンピュータによる 流体力学」, pp.161〜pp.162, (2003), シュプリンガー・ ジャパン.

(3) 日本機械学会編, 「流れの数值シミュレーション」, pp102 〜104, (1988), コロナ社.

(4) 大池, 福井大学卒業論文「粘弾性流体による急縮小流れ」, (1993). 